\section{IAC Netuno: A new black bean cultivar resistant to anthracnose and Fusarium wilt}

\author{
Alisson Fernando Chiorato ${ }^{1}$, Sérgio Augusto Morais Carbonell ${ }^{1}$, \\ Luiza Maria Capanema Bezerra ${ }^{1}$, Daiana Alves Silva ${ }^{1 *}$, João \\ Guilherme Ribeiro Gonçalves ${ }^{1}$, Luciana Lasry Benchimol-Reis ${ }^{2}$, \\ Cássia Regina Limonta Carvalho², José Antônio de Fátima \\ Esteves $^{1}$, Neli Cristina Belmiro dos Santos ${ }^{3}$ and Vera Nishigima \\ Paes de Barros $^{3}$
}

\begin{abstract}
IAC Netuno, a black common bean cultivar with high grain yield potential, $2968.20 \mathrm{~kg} \mathrm{ha}^{-1}$, upright plant architecture and Type II indeterminate growth habit, about a 90-day cycle, and 1000-seed weight of 230 grams, recommended for all common bean crop seasons in the state of São Paulo.
\end{abstract}

Keywords: Phaseolus vulgaris L., VCU trials, Colletotrichum lindemuthianum, Fusarium oxysporum, technological quality.

\section{INTRODUCTION}

Black beans (Phaseolus vulgaris L.) have a very important share in the Brazilian market, second only to the carioca (beige with brown stripes) type, which is the leader in terms of consumption, planted area, and production. Demand for black beans is related to regional eating habits. It can be considered a regulator of the carioca bean market because in seasons in which carioca beans have a higher price, consumers direct more of their purchases to black beans.

In Brazil, the market for dry edible bean with a black seed coat is concentrated in the states of Rio Grande do Sul, Santa Catarina, Paraná, and Rio de Janeiro and Minas Gerais. These areas are quite demanding concerning black bean quality. The beans should remain whole and dark after cooking and create a black broth. These aspects are important indicators for plant breeding programs.

According to IBRAFE (2017), other aspects of interest to the production chain regarding black bean are related to supplying the Brazilian internal market, which often depends on imports from countries such as China and Argentina, and the price paid to the producers. However, according to CONAB (2020), the black bean market remains stable and independent of the large price difference in relation to carioca beans and despite of the fall in imports due to the devaluation of the Brazilian Real against the US Dollar in 2019, there was a greater need for imports of this type of grain and the exports remained.

Growing black bean is often attractive to the producers when the carioca type is abundant on the consumer market; it allows greater profitability since it is an alternative to growing carioca bean.
Crop Breeding and Applied Biotechnology 20(3): e20442033, 2020 Brazilian Society of Plant Breeding. Printed in Brazil http://dx.doi.org/10.1590/198470332020v20n3c37 \author{
(1)
}


The bean breeding program of the Instituto Agronômico de Campinas (IAC), Brazil, has directed its studies to high yield, production adaptability and stability, and tolerance to main bean diseases, such as bacterial blight, anthracnose, and Fusarium wilt. The current direction of research and development of dry edible bean in IAC has also been to present results in line with demands from the production chain, as in technological quality and the development of specialty grains.

In general, the results of studies developed by research organizations in recent decades have led to an increase in total production and a decrease in growing area, which shows an expressive increase in yield beginning in the 1984/1985 crop season. A significant part of this result is attributable to some crop management factors, but plant breeding is the largest factor responsible for integrating genetic resistance to diseases and increasing the yield capacity of cultivars (Carbonell et al. 2010, Barili et al. 2015, Henrique et al. 2015, Azevedo et al. 2015, Melo et al. 2017, Pelegrini et al. 2017).

The aim of this article is to present data on the GEN PR10-4-4/24 line obtained through Value for Cultivation and Use (Valor de Cultivo e Uso - VCU) trials performed in the state of São Paulo, Brazil, in three growing seasons from 2013 to 2015. The new cultivar called IAC Netuno was registered in the Brazilian Cultivar Registry (Registro Nacional de Cultivares - RNC/MAPA) under number 35645 and is protected in the National Cultivar Protection System (Sistema Nacional de Proteção de Cultivares - SNPC/MAPA) under certification number 20170157. The seeds of IAC Netuno are available for purchase at IAC and in companies registered with the IAC seed production system.

\section{GENETIC ORIGIN AND DEVELOPMENT}

The GEN PR10-4-4/24, IAC Netuno, line was developed from 2009 to 2015. In 2009, a single cross was made between the black seed coat cultivars IAC Una and IPR Tuiuiú, resulting in $22 F_{1}$ seeds. In 2010, the $22 F_{1}$ seeds were sown to obtain $F_{2}$ seeds. Starting with this generation, inoculations were made with the anthracnose pathogen, physiological races $31,65,81$, and 89 , resulting in the selection of 38 plants resistant to the physiological races tested. These plants were transplanted in pots and grown in a greenhouse to obtain the $F_{2: 3}$ generation.

After that, in 2010, in Campinas, the experiment was carried out in field conditions under the occurrence of the pathogen Fusarium oxysporum, in which $38 \mathrm{~F}_{2: 3}$ progenies were sown and evaluated in regard to tolerance to Fusarium wilt. Progeny selection was made, obtaining 15 tolerant progenies, which did not present the disease incidence, giving rise to the next generation, $\mathrm{F}_{2: 4}$.

In the following year, 2011, the $15 \mathrm{~F}_{2: 4}$ progenies were sown in Campinas and once more grown in an area with natural contamination of Fusarium oxysporum. A total of 44 plants were selected in this generation. Still in 2011, in October, the 44 previously selected plants were self-pollinated, giving rise to $495 \mathrm{~F}_{2: 5}$ lines, and then once more evaluated in an area contaminated by Fusarium oxysporum. In this generation, due to the plants having a high degree of homozygosity, the genotypes selected were considered lines, and selections were made among lines and no longer within progenies. From the 44 initial progenies, 27 advanced lines were selected. From this step on, the lines were denominated with the abbreviation PR10-4-4/1 to PR10-4-4/27, representing the total number of lines selected.

In 2012, field evaluations began of the $27 \mathrm{~F}_{2: 5}$ lines selected derived from the cross between the cultivars IAC Una and IPR Tuiuiu. These evaluations mainly focused on grain yield, plant architecture, sieve classification, and seed coat color. In addition, reaction of the lines was evaluated concerning resistance to diseases naturally occurring in the field, such as angular leaf spot, bacterial blight, and Fusarium wilt. The lines showed tolerance to these diseases. The evaluations contained two controls with the black seed coat, the commercial cultivars IAC Diplomata, IAC Una. Based on the evaluations made up to this time, the line chosen was denominated with the abbreviation GEN PR10-4-4/24.

Since it exhibited good yield and tolerance to the main diseases, the line GEN PR10-4-4/24 was selected together with 10 other advanced lines developed by IAC to compose the VCU trials that began in the rainy crop season in 2013. The trials were conducted in the state of São Paulo in 14 environments over 3 different crop seasons (the rainy, the dry, and the winter crop seasons).

\section{YIELD CAPACITY}

The VCU trials were conducted in 14 environments over three different crop seasons from 2013 to 2015. Table 1 highlights the mean yield obtained in the experiments. 
The results of the VCU trials described in Table 1 showed that the GEN PR10-4-4/24 line had a mean yield of 2968.20 $\mathrm{kg} \mathrm{ha}^{-1}$, productive averages higher than the standard controls (IAC Una and IAC Diplomata) of the VCU trials, even it did not statistically differ from the check cultivars compared by mean testing of Dunnett at $5 \%$ probability. The IAC Diplomata control had mean yield of $2625.90 \mathrm{~kg} \mathrm{ha}^{-1}$, and the cultivar IAC Una had mean yield of $2666.80 \mathrm{~kg} \mathrm{ha}^{-1}$ (Table 2).

\section{OTHER CHARACTERISTICS}

The IAC Netuno cultivar has upright plant architecture and Type II indeterminate growth habit with resistance to Fusarium wilt (Fusarium oxysporum), 1000-seed weight of about 260 grams. Its average cycle is 90 days from emergence to physiological maturity in accordance with environmental growing conditions. In relation to inoculations, under controlled laboratory conditions and later observation in the production field over the segregating generations, the cultivar proved to be resistant to anthracnose (Colletotrichum lindemuthianum).

No significant difference among the genotypes was observed for mean cooking time (minutes) and protein content (\%). However, analysis of cooking time for the rainy crop season (five environments) showed that the cultivar IAC Netuno had the lowest mean cooking time (33.2 $\mathrm{min}$ ) (Table 3).

Table 1. Grain yield $\left(\mathrm{kg} \mathrm{ha}^{-1}\right)$, experimental coefficient of variation (CV\%), and least significant difference (Dunnett-5\%) compared to the best standard cultivar in regard to cultivation in the three common bean crop seasons, as well as compared to the overall mean of the characteristic, evaluated in 14 environments in the state of São Paulo in the VCU trials in the two-year period of 2013/2014/2015

\begin{tabular}{lcccc}
\hline $\begin{array}{l}\text { Common } \\
\text { bean cultivar }\end{array}$ & $\begin{array}{c}\text { Crop season } \\
\left(\mathrm{kg} \mathrm{ha}^{-1}\right)\end{array}$ & $\begin{array}{c}\text { Mean } \\
\text { (5 environments) }\end{array}$ & $\begin{array}{c}\text { Dry } \\
(5 \text { environments) }\end{array}$ & 2013/2014/2015 $\left(\mathrm{kg} \mathrm{ha}^{-1}\right)$ \\
\cline { 2 - 4 } & 3229.6 & 2052.5 & 3655.2 & 2968.2 \\
\hline IAC Netuno & 2717.6 & 1869.2 & 3411.5 & 2625.9 \\
IAC Diplomata & 2923.6 & 1944.2 & 3120.8 & 2666.8 \\
IAC UMA & 3174.00 & 2780.00 & 3477.00 & 3143.7 \\
Mean $\left(\mathrm{kg} \mathrm{ha}^{-1}\right)$ & 14.93 & 16.8 & 12.9 & 18.6 \\
CV $(\%)$ & 432 & 372 & 570 & 458 \\
LSD $(\mathrm{kg} \mathrm{ha-1})^{*}$ & & & & 4 \\
\hline
\end{tabular}

* LSD (0.05).

Table 2. Average performance of the cultivar IAC Sintonia and of the check cultivars IAC Milênio and IPR Tangará for main characteristics as: Cycle (C), Sieve yield (SY), mass of thousand grain (MTG), Antracnose reaction (AR), Fusarium wilt reaction (FWR), Angular leaf spot reaction (ALSR) and Bacterial blight reaction (BBR)

\begin{tabular}{|c|c|c|c|c|c|c|c|}
\hline \multirow{2}{*}{ Common bean cutivar } & \multirow{2}{*}{$\begin{array}{c}\mathbf{C} \\
\text { (days) }\end{array}$} & \multirow{2}{*}{$\begin{array}{c}\text { SY } 12 \\
(\%)\end{array}$} & \multirow{2}{*}{$\begin{array}{c}\text { MTG } \\
\text { (g) }\end{array}$} & AR & FWR & ALSR & BBR \\
\hline & & & & \multicolumn{4}{|c|}{ (Mixture of isolates) } \\
\hline IAC Netuno & 90 & 90 & 260 & $\mathrm{R}$ & MR & $\mathrm{MR}$ & $\mathrm{MR}$ \\
\hline IAC Una & 90 & 80 & 220 & $\mathrm{R}$ & $\mathrm{MR}$ & $S$ & $\mathrm{~S}$ \\
\hline
\end{tabular}

R: Resistant to the pathogen; MR: Moderately resistant to the pathogen; S: Susceptible to the pathogen.

Table 3. Technological and nutritional quality: mean values of cooking time by the Mattson Cooker and protein content in common bean seeds, black color, grown in the two-year period of 2013/2014/2015 in 14 environments in the state of São Paulo in VCU trials (Dunnett<0.05)

\begin{tabular}{|c|c|c|c|c|c|c|}
\hline \multirow[b]{2}{*}{ Crop seasons } & \multicolumn{2}{|c|}{ IAC Netuno } & \multicolumn{2}{|c|}{ IAC Diplomata } & \multicolumn{2}{|c|}{ IAC Uma } \\
\hline & $\begin{array}{l}\text { Cooking time } \\
\text { (min.) }\end{array}$ & $\begin{array}{c}\text { Protein content } \\
(\%)\end{array}$ & $\begin{array}{l}\text { Cooking time } \\
(\text { min. })\end{array}$ & $\begin{array}{c}\text { Protein content } \\
(\%)\end{array}$ & $\begin{array}{l}\text { Cooking time } \\
\text { (min.) }\end{array}$ & $\begin{array}{c}\text { Protein content } \\
(\%)\end{array}$ \\
\hline Rainy & 33.20 & 20.50 & 36.10 & 20.50 & 39.70 & 19.00 \\
\hline Dry & 31.30 & 21.50 & 29.70 & 20.50 & 31.70 & 20.50 \\
\hline Winter & 27.40 & 220 & 29.70 & 20.50 & 27.90 & 20.00 \\
\hline Mean & 30.63 & 21.33 & 31.83 & 20.50 & 33.10 & 19.83 \\
\hline
\end{tabular}

* LSD (0.05). 


\section{AF Chiorato et al.}

Between-row spacing of $50 \mathrm{~cm}$ and 12 plants per linear meter is recommended, resulting in 240.000 plants per hectare. The yield of the IAC Netuno cultivar will depend on the growing season, the growing region, and technological level of the farmer (fertilization, disease and weed control, water supply, and other production factors).

\section{TECHNICAL RECOMMENDATION AND SEED PRODUCTION}

Considering the mean yield obtained, resistance to anthracnose, and tolerance to pathogens of Fusarium wilt, bacterial blight, and angular leaf spot, and especially through exhibiting upright plant architecture, the cultivar IAC Netuno is recommended for cultivation in the rainy, dry, and winter crop seasons in the state of São Paulo, and it can also be grown in the rainy and dry crop seasons in the states of Paraná, Santa Catarina, Rio Grande do Sul, and Mato Grosso do Sul, Brazil.

\section{REFERENCES}

Azevedo CVG, Ribeiro T, Silva DA, Carbonell SAM and Chiorato AF (2015) Adaptabilidade, estabilidade e resistência a patógenos em genótipos de feijoeiro. Pesquisa Agropecuária Brasileira 50: 912-922.

Barili LD, Vale NM, Prado AL, Carneiro JES, Silva FF and Nascimento M (2015) Genotype-environment interaction in common bean cultivars with carioca grain cultivated in Brazil in the last 40 years. Crop Breeding and Applied Biotechnology 15: 244-250.

Carbonell SAM, Chiorato AF, Carvalho CRL, Ramos Junior EU, Ito MK, Borges WLB, Ticelli M, Santos NCB and Gallo PB (2010) IAC Formoso: new carioca common bean cultivar. Crop Breeding and Applied Biotechnology 10: 374-376.

CONAB - Companhia Nacional de Abastecimento (2020) Acompanhamento da safra brasileira grãos. V. 7, safra 2019/20. Available at: <http:// www.conab.gov.br/>. Accessed on June 25, 2020.
Henrique FH, Carbonell SAM, Ito MF, Gonçalves JGR, Sasseron GR and Chiorato AF (2015) Classification of physiological races of Fusariumoxysporum f. sp. phaseoli in common bean. Bragantia 74: 84-92.

IBRAFE - Instituto Brasileiro do Feijão e Pulses (2017) Preço nacional do feijão. Available at: <http://www.ibrafe.org>. Accessed on November 10, 2017

Melo LC, Pereira HS, Faria LC, Souza TLPO, Wendlan A, Díaz JLC, Carvalho HWL, Melo CLP, Costa AF, Magaldi MCS and Costa JGC (2017) BRS FC402: high-yielding common bean cultivar with carioca grain, resistance to anthracnose and fusarium wilt. Crop Breeding and Applied Biotechnology 17: 67-71.

Pelegrini, DF, Capanema LM and Hasparyk RG (2017) Dinâmica da produção de feijão no Brasil: progresso técnico e fragilidades. Informe Agropecuário 38: 1-20.

(cc) EY This is an Open Access article distributed under the terms of the Creative Commons Attribution License, which permits unrestricted use, distribution, and reproduction in any medium, provided the original work is properly cited. 